\title{
Forthcoming events
}

The 5th Congreas of the ABEAN Federation for Paychiatry and Mental Fealth and the 9th AszaN Forum on Child and Adoleacent Pajchiatry concurrent with the 3rd Biennial Meeting of the Indonesian Pajchiatric Asecciation will be held from 16-19 January 1995 in Bandung, Indonesia. Further information: Department of Psychiatry, Faculty of Medicine. University of Indonesia, No. 6 Salemba raya 6 , Jakarta 10430, Indonesia (telephone 021337 559).

A one-day national conference on Understanding Memory Dyofunction, organised by the Brain Research Association, will be held on 9 February 1995 at the University of Leicester. Further information: Dr Jon Scott, Department of Cell Physiology and Pharmacology. University of Leicester, PO Box 138, Leicester LEl 9HN (telephone 0533 523083; fax 0533 525045).

A conference Pro-active Approaches to the Treatment and Integration of Mentally Disordered Ofenders will be held in Madrid from 5-8 March 1995. Further information: Capital Conferences, 8a White Hart Parade, London Road, Blackwater, Camberley, Surrey GU17 9AD or Dorothy Tonak, Little Adstock, Buckingham MK18 2HT (telephone and fax 0296 713439).

The 3rd st George's Eating Disorders conference: Engaging the 'patient' will be held on 6 and 7 March 1995. Further information about this and other conferences and publications: Philippa Weitz, The Conference Unit, Department of Mental Health Sciences, St George's Hospital Medical School, Cranmer Terrace, London SW17 ORE (telephone 081725 5534; fax 081725 3390).

International Congress II sponsored by National Association for the Dually Diagnosed, European Ascociation on Mental Bealth in Mental Retardation and Tufts University School of Medicine will be held in
Boston. Massachusetts from 8-11 March 1995. Topics include diagnosis and assessment, psychopharmacology. sexual behaviours. Further information: Dr Robert Fletcher, 110 Prince Street, Kingston, New York 12401, USA (telephone 914331 4336; fax 914331 4569).

TAPS 10th Annual Conference will be held on 13 July 1995 at Westminster Central Hall, London SW1. Further information: TAPS Research Unit, Hampstead Group Practice Building, 69 Fleet Road, London NW3 $8 U$.

The 12th International Congress of Group Peychotherapy will be held in Buenos Aires from 28 August-1 September 1995 (pre-Congress Institute 26-27 August) with the theme Groups on the Threshold of a New Century. Final call for papers, workshops, posters, etc. 30 Aprll 1995. Further information: Congress Office, Paraquay 2475, 1121 Buenos Aires, Argentina (telephone 5419613445 ; fax 5419635075 ) or Dr S. Whiteley, 33 Wheelers Lane, Brockham, Surrey RH3 7LA (telephone 0737 843446; fax 0737 843634).

\section{Courses}

A course Traumatic Incident Reduction, a treatment technique for PT8D will be held from 27-31 March 1995. Further information about this and other courses: Pauline Swift, Educational Services Manager, Trauma After Care Trust, Buttfields, The Farthings, Withington, Glos. GL54 4DF (telephone 0242 890306).

\section{Special interest groups}

The Special Interest Groups for Biological Psychiatry and Perinatal Psychiatry have now been formally established. Inaugural meetings for these groups will take place during the College's Winter Meeting in Glasgow. Further details will be included in the Winter Meeting programme. 